\title{
Lucjan ŚwITo: Zawarcie małżeństwa przez petnomocnika $w$ formie wyznaniowej ze skutkami cywilnymi $w$ prawie polskim [Entering into a marriage by proxy in the denominational form with civil consequences under Polish law]. Olsztyn: Wydawnictwo UWM, 2019, 254 pp.
}

Marriage as a form of legal union between a man and a woman has accompanied human beings from their very beginning. To some extent, it was treated not only in a legal way, but also as a form of a cultural and religious rite. At the dawn of Christianity, before the theology of marriage had come into existence, the Christians followed the already existing models of entering into marriage inherited from Judaism, and later from the Roman Empire.

The monograph of Fr. Lucjan Świto is an attempt to look at the special form of entering into a marriage by proxy in the denominational form with civil consequences under Polish law. Entering into a marriage by proxy applies both to a marriage concluded exclusively in the secular form, that is, before a registrar or a consul, and to a marriage concluded in the denominational form with consequences in the civil law. The latter situation takes place when spouses, in the presence of a cleric, simultaneously declare their will to conclude a marriage which is subject to Polish law.

The book titled Zawarcie matżenstwa przez petnomocnika $w$ formie wyznaniowej ze skutkami cywilnymi w prawie polskim [Entering into a marriage by proxy in the denominational form with civil consequences under Polish law] consists of four chapters, each preceded by a list of abbre- 
viations and a separate introduction. Lucjan Świto made an attempt to answer the main research problem whether the internal law of churches and religious associations, for which the Polish legislator allows the possibility of entering into marriage with civil-law consequences, provides for the possibility of concluding a marriage by proxy. While answering the question, the author based his elucidation of the issue in question on the internal legal regulations - the own law - of the following churches and religious associations: the Catholic Church (Roman Catholic Church, Orthodox Catholic Churches in Poland: Greek Catholic, Armenian and Neo-Uniate), the Seventh-day Adventist Church in the Polish Republic, the Polish Autocephalous Orthodox Church, the Baptist Christian Church in the Polish Republic, the Evangelical Church of Augsburg Confession in the Polish Republic, the Evangelical Methodist Church in the Polish Republic, the Evangelical Reformed Church in the Polish Republic, the Polish Catholic Church in the Polish Republic, the Old Catholic Mariavite Church in the Polish Republic, the Pentacostal Church in the Polish Republic, and Jewish Religious Communities in the Polish Republic.

This publication is a very interesting study provoking reflection on entering into a marriage by proxy in the denominational form with civil consequences under Polish law. At the same time, this reflection is strongly integrated into the ecumenical dialogue that focuses on Church-legal regulations and concerns detailed solutions in the field of relations between churches and religious associations. Moreover, the book will allow practitioners and theorists of Church law and internal law of churches and religious associations in Poland to take a stance on the issue of entering into a marriage by proxy in the denominational form with civil consequences. This is the first study in the Polish legal literature on entering into a marriage by proxy in the denominational form with civil consequences under Polish law. Lucjan Świto not only focused on Church-legal regulations, but also presented a wider dimension of relations taking place between churches and religious associations. The work is also part of the celebrations of the 55th anniversary of the Decree on Ecumenism Unitatis redintegratio of the Second Vatican Council. This Decree enacted on 21 November 1964 became a landmark document for the ecumenical involvement of the Roman Catholic Church with other churches and religious associations.

Without any doubt the book the reviewed book will get a great number of readers, among whom will be clergy of various Christian denominations and lawyers. 